\title{
Hepatic macrophages in homeostasis and liver diseases: from pathogenesis to novel therapeutic strategies
}

\author{
Cynthia Ju ${ }^{1}$ and Frank Tacke ${ }^{2}$
}

Macrophages represent a major cell type of innate immunity and have emerged as a critical player and therapeutic target in many chronic inflammatory diseases. Hepatic macrophages consist of Kupffer cells, which are originated from the fetal yolk-sack, and infiltrated bone marrow-derived monocytes/macrophages. Hepatic macrophages play a central role in maintaining homeostasis of the liver and in the pathogenesis of liver injury, making them an attractive therapeutic target for liver diseases. However, the various populations of hepatic macrophages display different phenotypes and exert distinct functions. Thus, more research is required to better understand these cells to guide the development of macrophage-based therapeutic interventions. This review article will summarize the current knowledge on the origins and composition of hepatic macrophages, their functions in maintaining hepatic homeostasis, and their involvement in both promoting and resolving liver inflammation, injury, and fibrosis. Finally, the current strategies being developed to target hepatic macrophages for the treatment of liver diseases will be reviewed.

Cellular \& Molecular Immunology (2016) 13, 316-327;doi:10.1038/cmi.2015.104;published online 24 February 2016

Keywords: macrophage; chemokine; liver fibrosis; monocyte; microbiome

\section{INTRODUCTION}

Macrophages, also termed phagocytes, are myeloid immune cells that are widely distributed throughout the tissues in the body. They recognize, ingest, and degrade cellular debris, foreign material, or pathogens and exert a central function in orchestrating inflammatory processes. ${ }^{1}$ Hepatic macrophages hold central positions in maintaining homeostasis in the liver as well as in the pathogenesis of acute or chronic liver injury. This makes them in principle an attractive target for novel therapies for liver diseases. However, macrophages exert a wide range of different functions in the liver and consist of functionally opposing cellular subsets, thus rendering the development of macrophagebased interventional strategies quite challenging so far. ${ }^{2}$

Intensive research on animal models of liver injury and on samples from patients with liver diseases has elucidated the complex heterogeneity of macrophages in the liver. Monocytes (the circulating precursors) and macrophages in the liver can be distinguished based on their origin, their migratory behavior, their differentiation, certain marker expression, and, most importantly, their functions during homeostasis and disease
(Table 1). However, these characteristics cannot be considered static, as macrophages are extraordinarily versatile cells. For instance, macrophages respond to environmental signals from tissue in a highly diversified manner, leading a wide spectrum of different 'polarization states' in vitro and in vivo. ${ }^{3,4}$ Liver-infiltrating pro-inflammatory macrophages can rapidly develop into restorative, tissue-repairing cells in case of cessation of liver injury. ${ }^{5}$ In this review article, we will summarize the current knowledge on the role of hepatic macrophages in maintaining homeostasis, promoting and resolving inflammation, repairing tissue, and causing fibrosis progression or regression. With a better understanding of the heterogeneity and functional diversity of these cells, macrophage-directed therapies may become a promising future option for the treatment of liver diseases.

\section{ORIGIN AND COMPOSITION OF HEPATIC MACROPHAGES}

One of the most important paradigm shifts in macrophage biology during recent years referred to the origin of tissue macrophages, including macrophages in the liver. ${ }^{1}$ While it has been long believed that tissue macrophages originate from

\footnotetext{
${ }^{1}$ Skaggs School of Pharmacy and Pharmaceutical Sciences and Integrated Immunology, University of Colorado Anschutz Medical Campus, Aurora, USA and ${ }^{2}$ Department of Medicine III, University Hospital Aachen, Aachen, Germany

Correspondence: Cynthia Ju, PhD, University of Colorado Anschutz Medical Campus, 12850 East Montview Blvd, Aurora, Colorado, USA.

Email: cynthia.ju@ucdenver.edu;

Frank Tacke, M.D., PhD, Department of Medicine III, University Hospital Aachen, Pauwelsstrasse 30, 52074 Aachen, Germany.

Email: frank.tacke@gmx.net
}

Received: 26 October 2015; Revised: 21 November 2015; Accepted: 21 November 2015 
Table 1 Macrophage heterogeneity in healthy and diseased liver

\begin{tabular}{lc}
\hline \multicolumn{1}{c}{ Kupffer cells } & Origin of hepatic macrophages \\
\hline $\begin{array}{l}\text { Liver-resident, stationary, derived from a local stem cell seeded during } \\
\text { embryogenesis }\end{array}$ & $\begin{array}{l}\text { Derived from infiltrating blood monocytes, migratory, diverse functional } \\
\text { properties depending on microenvironment }\end{array}$ \\
\hline M1 macrophage polarization & Polarization of hepatic macrophages \\
\hline $\begin{array}{l}\text { Pro-inflammatory, anti-tumoral, induced by LPS or IFN } \gamma \text {, key cytokines } \\
\text { TNF, IL1 } \beta \text {, and IL-12, linked to Th1 T cells }\end{array}$ & $\begin{array}{l}\text { Anti-inflammatory, immune suppressive, pro-tumoral, induced by IL-4 } \\
\text { and IL-13, key cytokine IL-10, linked to Th2 T cells }\end{array}$ \\
\hline
\end{tabular}

Subsets of circulating monocytes

\begin{tabular}{|c|c|}
\hline Ly-6C ${ }^{\text {high }}$ monocytes & Ly- $6 C^{\text {low }}$ monocytes \\
\hline $\begin{array}{l}\text { Inflammatory mouse monocyte subset, rapid recruitment to sites of } \\
\text { inflammation, likely human counterpart: CD14 }{ }^{\text {high }} \text { monocytes }\end{array}$ & $\begin{array}{l}\text { Mature mouse monocyte subset with a characteristic patrolling pattern, } \\
\text { likely human counterpart: } \mathrm{CD} 14^{\mathrm{dim}} C D 16^{++} \text {monocytes }\end{array}$ \\
\hline
\end{tabular}

Functional macrophage subsets regarding liver immunology

\begin{tabular}{ll}
\hline \multicolumn{1}{c}{ Tolerogenic macrophages } & \multicolumn{1}{c}{ Immunogenic macrophages } \\
\hline $\begin{array}{l}\text { Mostly Kupffer cells during homeostasis, express MHC-II, PDL-1, IL-10, } \\
\text { and induce regulatory T cells }\end{array}$ & $\begin{array}{l}\text { Likely derived from infiltrating monocytes, express MHC-II and } \\
\text { costimulatory molecules (CD80, CD86), induce T cell responses }\end{array}$ \\
\hline \multicolumn{1}{c}{ Functional macrophage subsets regarding liver disease } \\
\hline \multicolumn{1}{c}{ Inflammatory macrophages } & Restorative macrophages \\
$\begin{array}{ll}\text { Promote liver inflammation and fibrosis, activation via TLR, release of } \\
\text { fibrogenic (via TGF- } \beta \text { ) }\end{array}$ & $\begin{array}{l}\text { Promote resolution of inflammation (anti-inflammatory cytokines) and } \\
\text { fibrosis (matrix metalloproteinases MMP-9, MMP-12, MMP-13), Ly-6Clow } \\
\text { expression in mice, post-phagocytic }\end{array}$ \\
\hline
\end{tabular}

Important dichotomies that have been introduced to describe the heterogeneity of monocyte and macrophage subsets in the liver.

circulating adult blood monocytes, it is now clear that many resident tissue macrophages are established during embryonic development and persist independent from blood monocytes in homeostasis. ${ }^{6}$ This dichotomy of macrophages is prototypically found in the liver. The liver harbors about $80 \%$ of all macrophages of the body and is furthermore patrolled by blood monocytes. ${ }^{2}$ The circulating blood monocytes can principally infiltrate the liver and give rise to monocyte-derived macrophages, but this is characteristic to liver injury. ${ }^{7}$ During homeostasis, the macrophages in the liver predominantly self-renew from resident stem cells that originated from the fetal yolk-sack. ${ }^{8-10}$ Most researchers call these hepatic macrophages Kupffer cells in order to distinguish the tissue-resident macrophages from infiltrating (monocyte-/bone marrow-derived) cells. ${ }^{2}$ In mouse models, innovative fate mapping strategies, multi-marker flowcytometric phenotyping and intravital microscopy are used to distinguish Kupffer cells from monocyte-derived macrophages. ${ }^{6,11}$ However, no single marker is currently able to definitely discriminate these populations. In human liver, CD68 has been proposed as an indicator, but non-exclusive marker for Kupffer cells. ${ }^{12}$ More recently, CD163L was proposed as a marker for tissue-resident macrophages, while CLEC5A might identify monocyte-derived pro-inflammatory macrophages. ${ }^{13}$

Blood monocytes, the circulating precursors for macrophages and dendritic cells, consist of subtypes as well, which are characterized by different Ly-6C (Gr-1) expression levels in mice. Ly-6C $\mathrm{C}^{\text {hi }}$ monocytes express the chemokine receptor CCR2 and rapidly infiltrate tissue upon injury, while Ly- $6 \mathrm{C}^{\text {low }}$ monocytes express higher levels of CX3CR1 and show a patrolling behavior in vivo. ${ }^{14}$ The human counterparts of these monocyte subsets are termed classical $\left(\mathrm{CD} 14^{++} \mathrm{CD} 16^{-}\right)$, intermediate $\left(\mathrm{CD} 14^{+} \mathrm{CD} 16^{+}\right)$, and non-classical $\left(\mathrm{CD} 14^{\mathrm{dim}} \mathrm{CD} 16^{++}\right)$monocytes. ${ }^{15}$ Intravital microscopy experiments in mice suggest that the Ly- $6 \mathrm{C}^{\mathrm{low}}$ monocytes crawl along the hepatic endothelium, ${ }^{16}$ possibly to orchestrate the disposal of apoptotic cells or other cellular debris. ${ }^{17}$ Such a crawling migratory behavior was also observed for classical and non-classical but not intermediate human monocytes on endothelial monolayers in vitro, indicating subtype-specific human monocyte migratory behavior patterns with distinct adhesion molecule dependence. ${ }^{18}$

Upon acute or chronic hepatic injury in mice, Ly- $6 \mathrm{C}^{\text {hi }}$ blood monocytes are massively recruited to the liver and predominate the macrophage pool. ${ }^{7}$ These monocyte-derived macrophages can form ring-like structures around defined areas of injury ${ }^{5}$ or accumulate around periportal regions in cases of widespread liver damage. ${ }^{19}$ Although these monocyte-derived macrophages initially exert pro-inflammatory and pro-fibrogenic actions, they can differentiate into Ly- $6 \mathrm{C}^{\text {low }}$ monocytederived macrophages 5 , which may foster tissue repair and injury resolution. ${ }^{20,21}$ The massive infiltration of monocytes is also a hallmark feature of acute and chronic liver injury in humans. ${ }^{12,22,23}$ 
HEPATIC MACROPHAGE FUNCTIONS IN HOMEOSTASIS Kupffer cells belong to the reticuloendothelial system in the liver, a highly dynamic and complex network, which constitutes a primary line of defense against invading microorganisms, functions as a sensor for altered tissue integrity and largely contributes to the upkeep of tissue homeostasis. ${ }^{24}$ Because the liver is constantly exposed to antigens from the intestine as well as low levels of bacterial endotoxins, many mechanisms suppress an 'accidental' activation of the immune system. Kupffer cells play a major role in maintaining immunological tolerance in the liver and in providing an anti-inflammatory micromilieu during homeostasis. ${ }^{24}$ For instance, Kupffer cells secrete the anti-inflammatory cytokine interleukin (IL)-10 in mouse $^{11}$ as well as in human liver. ${ }^{25}$ Although Kupffer cells express lower levels of MHC class II molecules than classical dendritic cells, they are able to interact with T cells. However, unlike dendritic cells, Kupffer cells favor the development of regulatory $\mathrm{T}$ cells, thereby promoting immune tolerance. In a mouse model using the systemic delivery of particulate antigen, Kupffer cells interact with T cells in an antigen-specific manner, expand IL-10 expressing regulatory $\mathrm{T}$ cells, and are able to establish a tissue-protective systemic tolerance against these antigens. $^{11}$

Several mechanisms have been identified that contribute to the tolerogenic features of Kupffer cells. On the one hand, Kupffer cells express relatively high levels of the T-cell inhibitory molecule PDL-1 in healthy liver, but low levels of co-stimulatory molecules. ${ }^{11}$ Moreover, when Kupffer cells are purified from healthy liver, they can induce regulatory $\mathrm{T}$ cells in vitro via the secretion of prostaglandins PGE2 and 15d-PGJ2. ${ }^{26}$ The pretreatment of Kupffer cells with IFN- $\gamma$ upregulates the enzyme indoleamine-2,3-dioxygenase (IDO) that appears essential for the induction of a suppressive T-cell response. $^{27}$

Kupffer cells not only interact with $\mathrm{T}$ cells, but can also interact with many cellular components in the liver. For instance, Kupffer cells can initiate the recruitment of monocytes to the liver in case of injury, which is an important prerequisite for liver regeneration, ${ }^{28}$ and they also cross-talk with hepatic stellate cells (HSCs). ${ }^{29}$ However, due to their rather stationary behavior, Kupffer cells are not optimally suited to migrate to sites of injury or to interact with dynamic processes such as angiogenesis. Infiltrating monocytes, on the other hand, are motile and better suited to interact with the vasculature, promoting an ordered vascular growth during liver regeneration ${ }^{30}$ or during chronic injury. ${ }^{31}$ Nevertheless, although infiltrating monocyte-derived macrophages can resemble the phenotype of Kupffer cells quite rapidly after virus-induced inflammation ${ }^{32}$ or after acetaminophen (APAP)-induced hepatotoxicity, ${ }^{33}$ they remain functionally distinct.

\section{HEPATIC MACROPHAGE FUNCTIONS IN ACUTE LIVER INJURY}

During liver injury, resident Kupffer cells are important in the initial response to injury by rapidly producing cytokines and chemokines, including IL-1 $\beta$, tumor necrosis factor (TNF) $\alpha$,
CCL2, and CCL5, resulting in the recruitment of other immune cells, such as monocytes. Both acute and chronic liver injuries are characterized by a dramatic expansion of the hepatic macrophage population owing to the massive influx of monocytes into the liver (Figure 1). For example, in mouse models of $\mathrm{CCl}_{4}$-induced liver fibrosis, the infiltration of Ly- $6 \mathrm{C}^{\mathrm{hi}}$ monocytes contributes to a threefold to fivefold expansion of hepatic macrophages. ${ }^{7}$ Consistent with the distinct chemokine receptor and adhesion molecule expression patterns on $\mathrm{Ly}-6 \mathrm{C}^{\text {hi }}$ and Ly-6C ${ }^{\text {low }}$ monocytes, ${ }^{15}$ the infiltrated monocytes are dominated by the Ly- $6 \mathrm{C}^{\text {hi }}$ subset. After transmigration into the liver, the Ly- $6 \mathrm{C}^{\text {hi }}$ monocytes differentiate into Ly- $6 \mathrm{C}^{+}$macrophages, which are thought to exhibit pro-inflammatory and pro-fibrogenic functions (Figure 1). Accumulating evidence suggests that the tissue micro-environmental factors during disease conditions could promote the switch of $\mathrm{Ly}-6 \mathrm{C}^{+}$macrophages into Ly-6C ${ }^{\text {low }}$ macrophages (Figure 1). To therapeutically target hepatic macrophages in acute and chronic liver diseases, it is important to understand the respective roles of resident Kupffer cells and infiltrated Ly-6C hi and Ly-6C ${ }^{\text {low }}$ macrophages in various types of liver diseases. The different models of acute liver injury, as reviewed in this article, yielded interesting context-dependent functions of the hepatic macrophage subsets in either propagating or limiting the immune response in acute liver disease.

\section{Acetaminophen hepatotoxicity}

Overdose APAP can cause severe liver damage with the potential to progress to liver failure, which accounts for nearly half of the liver failure cases in the USA and a significant portion in Europe. APAP-induced direct damage to hepatocytes triggers the activation of resident Kupffer cells and the massive recruitment of circulating monocytes in mice (Figure 1). ${ }^{33,34}$ It was observed that the number of resident Kupffer cells reduced significantly by $24 \mathrm{~h}$ after APAP challenge and began to recover by $72 \mathrm{~h}$. Although it is clear now that Kupffer cells are established prenatally by yolk-sack progenitor cells, ${ }^{9,10}$ it remains a question whether circulating monocytes contribute to the replenishment of Kupffer cells during liver injury. In the model of APAP-induced liver injury (AILI), the replenishment of Kupffer cells is mainly achieved by self-renewal rather than from infiltrating monocytes. ${ }^{33}$ Consistent with this finding, it has been reported that Kupffer cells expand from resident progenitor cells during parasite infection where Th2 immunity dominates. $^{35}$

Hepatic macrophages were initially thought to contribute to AILI through their production of pro-inflammatory cytokines and mediators, such as TNF $\alpha$ and IL-1 $\beta^{36,37}$. However, macrophages are also the main source of IL-10, IL-4, and IL-13, all of which can protect against AILI. ${ }^{38-40}$ In line with a protective role of Kupffer cells, depletion of these cells was shown to exacerbate AILI. ${ }^{41,42}$ Aside from activating Kupffer cells, APAP challenge causes the recruitment of circulating monocytes in a CCR2-dependent manner. ${ }^{34}$ A more recent study further separated the infiltrating macrophages into Ly- $6 \mathrm{C}^{\text {hi }}$ monocytes, which are recruited into the liver in a CCR2-dependent fashion, 

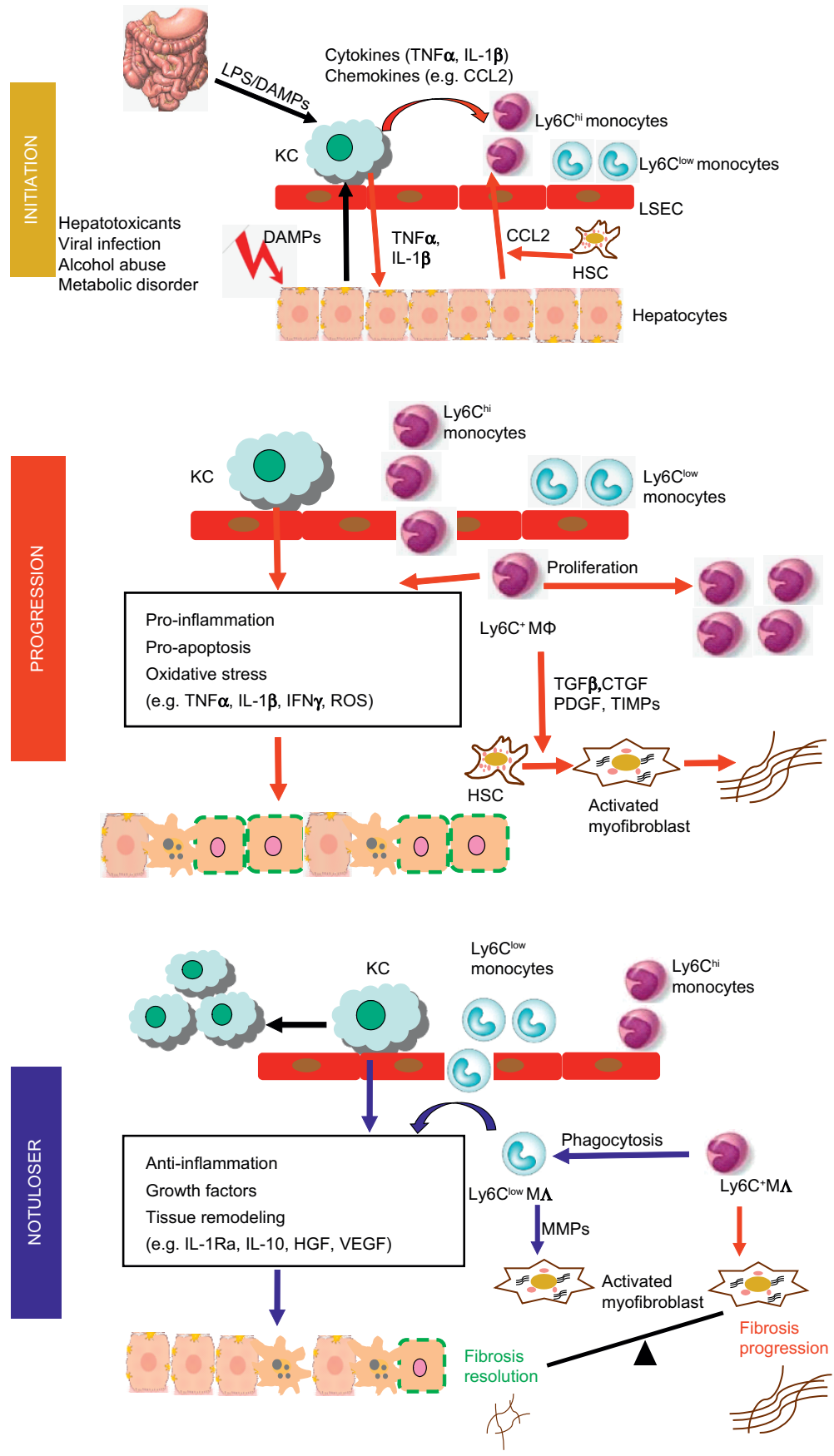

Figure 1 Involvement of hepatic macrophage populations during the initiation, progression and resolution of liver injury in mouse models. In the initial phase, hepatocyte damage triggers the release of damage-associated molecular pattern molecules (DAMPs) which stimulate Kupffer cell (KC) activation activation. Endotoxin from the gut-liver axis may additionally endorse Kupffer cell activation. Activated Kupffer cells secrete proinflammatory cytokines, including IL-1 $\beta$ and TNF $\alpha$, which contribute to hepatocyte injury. Hepatocytes, stellate cells and Kupffer cells secrete chemokines such as CCL2 that promotes the recruitment of Ly- $6 C^{\text {hi }}$ monocytes into the liver, where they develop into Ly- $6 C^{+}$macrophages. These cells promote the progression of liver injury by secreting pro-inflammatory cytokines and producing ROS. During chronic injury, Ly-6C ${ }^{+}$macrophages also trigger HSC activation and promote myofibroblast production of extracellular matrix through releasing pro-fibrotic mediators, such as tumor growth factor (TGF)- $\beta$, connective tissue growth factor (CTGF), PDGF, and tissue inhibitor of matrix metalloproteinase (TIMPs). Phagocytosis of dead cells initiates the resolution of inflammation and tissue restoration. Upon phagocytosis or other resolution stimuli, the Ly- $6 \mathrm{C}^{\text {hi }}$ macrophages switch to Ly- $6 \mathrm{C}^{\text {low }}$ macrophages that exhibit a restorative phenotype. The Ly- $6 \mathrm{C}^{\mathrm{low}}$ macrophages, as well as Kupffer cells produce anti-inflammatory mediators, such as IL-1 receptor antagonist (IL-1Ra) and IL-10. They release growth factors, including hepatocyte growth factor (HGF) and VEGF. Moreover, the Ly-6C ${ }^{\text {low }}$ macrophages produce matrix metalloproteinases (MMP-9, -12, -13) and promote the degradation of excessive extracellular matrix proteins. Overall, the phenotype and functional heterogeneity of hepatic macrophages play critical roles in determining the balance between the mechanisms of progression and resolution of tissue injury during both acute and chronic liver injuries. 
and Ly-6C ${ }^{\text {low }}$ monocyte-derived macrophages (Figure 1). ${ }^{33}$ CCR $2^{-1-}$ mice or anti-CCR2 antibody-treated mice exhibit delayed recovery from AILI, suggesting that the infiltrated macrophages may contribute to tissue repair after acute injury. ${ }^{33,34}$ In the combined absence of Kupffer cells and infiltrating macrophages, tissue repair is much more significantly impaired, further supporting a protective function of hepatic macrophages in AILI. ${ }^{21}$ Moreover, a recent study in mice indicated that the augmentation of both, Kupffer cells and monocyte-derived macrophages, via macrophage-colony stimulating factor (CSF1) might hold beneficial therapeutic potential in AILI by facilitating hepatocyte regeneration and restoring innate immune functions. ${ }^{43}$

\section{Concanavalin A-induced hepatitis}

Concanavalin A (ConA) is a plant lectin that acts as a $\mathrm{T}$ cell mitogen and causes $\mathrm{T}$ cell-mediated hepatotoxicity. Thus, ConA-induced liver injury in mice represents a commonly used animal model of autoimmune liver disease. Aside from stimulating $\mathrm{T}$ cells, ConA also activates liver resident Kupffer cells to produce $\mathrm{TNF} \alpha$ and IFN $\gamma$, which are key factors that cause hepatocyte damage. ${ }^{44,45}$ Kupffer cells also facilitate a Th1 immune response, thereby contributing to ConA hepatotoxicity ${ }^{46}$. Moreover, Kupffer cells and regulatory T cells produce IL-10 upon repeated exposure to ConA and cause immune tolerance. ${ }^{47,48}$ The data emphasize the relevance of Kupffer cell-T cell interactions for immune homeostasis as well as for autoimmunity.

\section{Ischemia/reperfusion-induced liver injury}

Ischemia/reperfusion (I/R)-induced liver injury may occur in a number of clinical settings such as trauma, shock, liver surgery, and liver transplantation ${ }^{49}$. During I/R injury, Kupffer cells are activated to produce reactive oxygen species (ROS) and secrete TNF $\alpha$, IL-1 $\beta$, and chemokines, which contribute to hepatocyte death, endothelial damage and recruitment, and activation of leukocytes ${ }^{50}$. Consistent with a pathological role of Kupffer cells, depletion of these cells attenuates I/R liver injury. ${ }^{51-54}$ Interestingly, some studies have reported a protective function of Kupffer cells during I/R. The protection appears to be mediated by the release of anti-inflammatory IL-10 and production of antioxidant hemeoxygenase by Kupffer cells. ${ }^{54-56}$ Monocyte-derived macrophages are recruited into the liver at the later phase of ischemia and they are involved in sustaining the tissue inflammation and destruction. ${ }^{57}$

\section{Liver injury as result of parasite infection}

Infection by the protozoan parasite Entamoeba histolytica causes hepatocyte damage in focal areas leading to amebic liver abscess (ALA). Selective depletion of Kupffer cells using liposome-entrapped clodronate or inhibition of monocyte infiltration using CCR2 ${ }^{-1-}$ mice revealed that Kupffer cells and inflammatory Ly- $6 \mathrm{C}^{\text {hi }}$ monocytes, through producing $\mathrm{TNF} \alpha$, are main effector cells responsible for liver destruction during ALA ${ }^{58}$ Trypanosoma congolense infection causes inflammatory response syndrome (SIRS) that is initiated by liver injury. C57BL/6 mice are tolerant to T. congolense infectioninduced SIRS because of the accumulation of Ly- $6 \mathrm{C}^{\text {low }}$ macrophages in the liver. The Ly- $6 \mathrm{C}^{\text {low }}$ macrophages protect against liver injury by secreting IL-10 and inhibiting hepatocyte death caused by TNF $\alpha$ that is released by Ly- $6 \mathrm{C}^{+}$inflammatory monocyte. Moreover, the Ly- $6 \mathrm{C}^{\text {low }}$ macrophages promote the differentiation of the $\mathrm{Ly}-6 \mathrm{C}^{+}$monocytes into antiinflammatory macrophages. ${ }^{59}$ These data suggest that enhancing the accumulation and/or functionality of the Ly- $6 C^{\text {low }}$ macrophages may be an effective strategy to complement anti-microbial medication in treating liver injury caused by parasite infection.

\section{HEPATIC MACROPHAGE FUNCTIONS IN CHRONIC LIVER INJURY}

Chronic liver diseases can be caused by multiple etiologies such as alcohol abuse, viral infection, and autoimmune and metabolic disorders. Regardless of the etiology, the disease progresses from inflammation to liver fibrosis/cirrhosis and to hepatocellular carcinoma (HCC). Evidence from clinical and animal studies suggests that hepatic macrophages play important roles in all stages of chronic liver disease.

\section{Alcoholic liver disease}

Alcohol abuse is a leading cause of chronic liver disease that affects millions of people worldwide. Alcoholic liver disease (ALD) can eventually lead to liver cirrhosis and HCC. Clinical observations in patients with alcoholic hepatitis and fibrosis support the involvement of macrophages in the disease progression. The number of macrophages in the liver is increased in the early stage of fatty liver as well as the later stages of hepatitis and cirrhosis. ${ }^{60}$

It has been reported that hepatic levels of macrophage inflammatory genes are upregulated in alcohol-related cirrhotic patients. ${ }^{61}$ A recent study of liver samples from patients with alcoholic steatohepatitis demonstrates the presence of macrophages expressing receptors and cytokines associated with both M1 and M2 macrophages, suggesting the co-existence of different types of hepatic macrophages. ${ }^{62}$ Indicators of macrophage activation, such as neopterin and leukocyte function associated antigen 3, as well as cytokines such as IL-6, IL-8, IL-18, and chemokines are elevated in ALD patients. ${ }^{63-66}$ Moreover, circulating monocytes from ALD patients spontaneously produce TNF $\alpha$ and are more sensitive to lipopolysaccharide (LPS) stimulation. ${ }^{67,68}$ Animal models of ALD have demonstrated that acute and chronic ethanol administrations are associated with the activation of hepatic macrophages, which produce TNF $\alpha$, IL-6, CCL2, and ROS. ${ }^{69,70}$ Depletion of macrophages by gadolinium chloride $\left(\mathrm{GdCl}_{3}\right)$ or clodronate liposomes attenuated alcohol-induced liver inflammation. ${ }^{70,71}$ Resident Kupffer cells from alcohol-fed mice are sensitized to endotoxin and exhibit increased responses to LPS, resulting in elevated production of TNF $\alpha$ and CCL2 (Figure 1). ${ }^{72,73}$ A recent study also demonstrated that chronic alcohol feeding causes the accumulation of hepatic infiltrating monocytes/ macrophages in mice. ${ }^{74}$ The infiltrated macrophages consist 
of two subsets with differential expression levels of Ly-6C (Ly$6 \mathrm{C}^{+}$and Ly- $6 \mathrm{C}^{\text {low }}$ ) and distinct genetic profiles. The Ly- $6 \mathrm{C}^{+}$cells exhibit a pro-inflammatory tissue-damaging phenotype; in contrast, the Ly- $6 \mathrm{C}^{\text {low }}$ cells exhibit an anti-inflammatory and tissue protective phenotype. ${ }^{74}$ Furthermore, upon phagocytosis of apoptotic hepatocytes, Ly- $6 \mathrm{C}^{+}$macrophages appears to switch to Ly-6C ${ }^{\text {low }}$ macrophages (Figure 1). ${ }^{74}$ Although macrophages have emerged as a critical player in ALD, directly targeting some of their detrimental functions appears challenging in clinical practice; for instance, anti-TNF antibody application in severe alcoholic hepatitis did not translate into improved clinical outcome in patients. ${ }^{75}$ Further understanding their heterogeneity and functional diversity is therefore warranted for therapeutically targeting these cells.

\section{Viral hepatitis}

Hepatitis B virus (HBV) and hepatitis C virus (HCV) infections can result in chronic liver disease with increased risk for liver fibrosis/cirrhosis, hepatic failure, and HCC. ${ }^{76,77}$ Evidence suggests that hepatic macrophages play an important role in viral hepatitis. Because it is difficult to distinguish Kupffer cells from infiltrating macrophages, studies in this area often refer to hepatic macrophages as Kupffer cells and do not properly take macrophage heterogeneity into account when describing their functions. Evidence suggests that hepatic macrophages ('Kupffer cells') have a beneficial anti-viral effect in the early phase after infection, but appear to play a role in suppressing anti-viral immunity during chronic infection. While only few studies show HBV binding to Kupffer cells and causing activation, HCV and its proteins have been shown to activate Kupffer cells. ${ }^{78-80}$ In HCV infection, Kupffer cells increase in number ${ }^{81,82}$ and expression levels of activation markers such as CD163 and CD33. ${ }^{83,84}$ Moreover, they produce pro-inflammatory cytokines IL-1 $\beta$, IL-6, IL-18, and TNF $\alpha{ }^{78-80,85}$ Among these cytokines, Kupffer cell-derived TNF $\alpha$ promotes HCV entry of hepatoma cells; ${ }^{86}$ in contrast, IL-6, IL-1 $\beta$ and IFN $\gamma$ inhibit HCV replication, ${ }^{87-89}$ suggesting that Kupffer cells play diverse roles in modulating anti-viral activities by producing a variety of cytokines. Kupffer cells also express TRAIL, Fas-ligand, granzyme B, perforin, and ROS, which directly cause cytotoxicity of infected hepatocytes. ${ }^{90-92}$ On the contrary to their anti-viral effects, Kupffer cells produce immunomodulatory mediators, such as IL-10, TGF $\beta$, galectin-9, PD-L1, and PDL2, during chronic HBV and HCV infection. ${ }^{78,94-97}$ These factors can suppress anti-viral immunity through inhibiting $\mathrm{T}$ cell function or inducing $\mathrm{T}$ cell death. Aside from their involvement in modulating anti-viral immunity, Kupffer cells are thought to be involved in the fibrosis development during chronic viral infection. Although the causative role has not been demonstrated, the number of $\mathrm{CD} 14^{+} \mathrm{CD} 68^{+}$Kupffer cells is increased in patients with viral hepatitis, ${ }^{96}$, and Kupffer cells are known to produce pro-fibrogenic factors. ${ }^{98}$ In summary, there is growing appreciation of hepatic macrophages in viral hepatitis. The multifaceted or even opposing roles of these cells may be attributed to not only resident Kupffer cells but also infiltrating macrophages. Future research of the functional dif- ferences and respective contributions of the different populations of hepatic macrophages is warranted.

\section{Liver fibrosis}

Evidence suggests that Kupffer cells can activate HSCs through the production of profibrotic cytokines TGF $\beta$ and plateletderived growth factor (PDGF) ${ }^{99}$. On the other hand, Kupffer cells also express multiple matrix metalloproteinases (MMP-9, -12 and -13$)$ that promote extracellular matrix degradation and thus favor the resolution of fibrosis. ${ }^{100,101}$ More recent studies that distinguish hepatic macrophages using various cell surface markers reveal the critical roles of infiltrated macrophages in orchestrating liver fibrosis development and resolution (Figure 1). ${ }^{7,20,102}$ Using CD11b-diphteria toxin receptor (DTR) transgenic mice, researchers have demonstrated that targeted deletion of infiltrated macrophages during fibrosis development ameliorates fibrosis; however, depletion of these macrophages during the resolution phase exacerbates fibrosis. ${ }^{20,102}$ The pro- and anti-fibrotic functions of hepatic macrophages may be explained by the fact that different subsets of infiltrated macrophages play opposite roles in liver fibrosis. During the early phase of tissue injury, the recruited Ly- $6 \mathrm{C}^{\text {hi }}$ monocytes differentiate into pro-inflammatory macrophages, and they directly interact with HSCs to promote fibrosis through the production of TGF $\beta$ (Figure 1). ${ }^{7}$ The CCL2CCR2 pathway plays a critical role in hepatic recruitment of the Ly- $6 \mathrm{C}^{\text {hi }}$ monocytes. Both genetic deletion of CCR2 in $\mathrm{CCR} 2^{-1-}$ mice and pharmacological inhibition of CCL2 by the RNA-aptamer mNOX-E36 result in attenuation of liver fibrosis. ${ }^{7,31,103}$ These findings support a pro-fibrotic function of the Ly- $6 \mathrm{C}^{\text {hi }}$ macrophages. A recent study demonstrates that phagocytosis of cellular debris facilitates the phenotypic switch of the Ly- $6 \mathrm{C}^{\text {hi }}$ macrophages to the Ly- $6 \mathrm{C}^{\text {low }}$ subset. ${ }^{20}$ Two lines of evidence suggest that the Ly- $6 \mathrm{C}^{\text {low }}$ macrophage subset is the primary source of MMPs and plays a critical role in orchestrating fibrosis resolution. ${ }^{20}$ First, the depletion of this population caused a failure in scar remodeling. ${ }^{20}$ Second, treatment of mice with the CCL2 inhibitor, mNOX-E36, caused a significant increase of the Ly- $6 \mathrm{C}^{\text {low }}$ macrophages and accelerated the regression of experimental liver fibrosis in mice caused by carbon tetrachloride or methionine-choline-deficient diet. ${ }^{103}$ The finding further supports for the anti-fibrotic function of the Ly- $6 \mathrm{C}^{\text {low }}$ macrophages.

\section{Hepatocellular carcinoma}

HCC is the most common type of primary liver cancer and the third leading cause of cancer-related death in the world. ${ }^{104}$ In HCC, tumor-associated macrophages play important roles in tumor growth, angiogenesis, and metastasis through the production of a number of growth factors (PDGF $\beta$, vascular endothelial growth factor (VEGF), TGF $\beta$, and EGFR ligands), cytokines (IL-6, TNF $\alpha$, and IL-10), chemokines (CCL17, CCL22, CCL24, CXCL12, and IL-8), as well as other soluble factors (MMPs, osteopontin, and cyclooxyganse-2). ${ }^{104}$ In diethylnitrosamine-induced HCC in mice, induced HCC, pro-inflammatory activation of Kupffer cells during the early 
stages of chemical-induced carcinogenesis is important in tumor development. ${ }^{105,106}$ Once the primary tumor is established, the liver infiltrated macrophages appear to play a more prominent role than Kupffer cells in HCC progression. ${ }^{106}$ HCC-associated hepatic macrophages are often identified by immunohistochemical detection of $\mathrm{CD}_{6} 8^{+}$or $\mathrm{CD} 14^{+}$cells, and cell number correlates with HCC progression and reduced survival. ${ }^{107-110}$ Targeting macrophages may be an effective approach in therapy. The majority of tumor cells in HCC express high levels of glypican-3, which is a member of the glypican family of heparin-sulfate proteoglycans and it promotes the recruitment of macrophages into the tumors. Antibodies that target glypican-3 have been investigated in phase I clinical trials of advance HCC with promising results. ${ }^{111,112}$ Zoledronic acid, which is used to prevent skeletal complications associated with bone metastases, has also shown anti-tumor effect through targeting tumor-associated macrophages as it is phagocytosed by macrophages and induces apoptosis of the cells. ${ }^{113,114}$ The combination therapy of zoledronic acid and sorafenib to treat advanced HCC is being evaluated in phase II studies (NCT01259193).

\section{STRATEGIES FOR THERAPEUTIC TARGETING OF HEPATIC MACROPHAGES}

The essential roles of liver macrophages for maintaining tissue homeostasis, for initiating inflammatory responses in injury, as well as for promoting the progression, but also regression of liver disease emphasize that these processes are prime targets for novel therapeutic approaches. Several interventional concepts have been validated in experimental animal models and are currently being translated into clinical scenarios (see Table 2). However, quite a few obstacles hamper the direct translation from mouse models to human disease, including the relatively poor definition of hepatic macrophage hetero- geneity and subset-specific functions in human liver, the important contribution of etiology-specific factors (such as bile acids in cholangiopathies, lipids, and lipid products in non-alcoholic fatty liver diseases, adaptive immunity in viral hepatitis) to macrophage activation in patients with distinct types of liver diseases as well as the variable and slow-going course of disease progression in patients. ${ }^{2}$

Some of the promising strategies for therapeutic targeting of hepatic macrophages include (see Table 2):

Dampening Kupffer cell activation, e.g., by modifying the gut-liver axis;

Inhibiting inflammatory monocyte recruitment to injured liver, e.g., by targeting chemokine pathways;

Shaping hepatic macrophage function, e.g., by either influencing their polarization or inhibiting inflammatory effector molecules;

Augmenting the differentiation to restorative macrophages, e.g., by providing phagocytic stimuli.

\section{Dampening Kupffer cell activation via the gut-liver axis} In animal models as well as in patients with chronic liver diseases, increased levels of endotoxins reaching the liver via the portal vein accelerate hepatic inflammation and fibrosis, emphasizing the relevance of gut-liver interactions. ${ }^{115}$ In fact, patients with liver cirrhosis show characteristic alterations of their gut microbiota, with an enrichment of potentially more invasive bacterial strains ${ }^{116}$. The toll-like receptor (TLR)dependent activation of inflammatory pathways in Kupffer cells and stellate cells can be effectively inhibited by intestinal decontamination via broad-spectrum antibiotics in mouse models, which reduces the progression of liver fibrosis and also hepatocarcinogenesis within inflamed livers. ${ }^{29,117}$ Similarly, commensal microbiota, as compared to germ-free gut conditions, is protective in mouse models of liver fibrosis, emphas-

Table 2 Strategies for therapeutic targeting of hepatic macrophages (derived from experimental models of chronic liver injury)

\begin{tabular}{|c|c|c|}
\hline Target & Possible approach (selected from experimental models) & Reference(s) \\
\hline $\begin{array}{l}\text { Dampening Kupffer cell activation } \\
\text { by influencing the gut-liver axis }\end{array}$ & $\begin{array}{l}\text { - } \text { restoration of the normal microbiome, by application of probiotics, antibiotics or fecal } \\
\text { microbiota transfer; } \\
\text { - sequestering of deoxycholic acid (or other bile acids associated formation oxidative } \\
\text { stress and DNA damage); } \\
\text { - application of compounds that lead to elevated tightness of the intestinal barrier. }\end{array}$ & $29,115,117,118$ \\
\hline $\begin{array}{l}\text { Inhibition of }\left(\mathrm{Ly}-6 \mathrm{C}^{+}\right) \text {inflammatory } \\
\text { monocyte recruitment to the liver }\end{array}$ & $\begin{array}{l}\text { - pharmacological antagonism of CCL2 (MCP-1), e.g., by RNA aptamer molecules; } \\
\text { - pharmacological inhibition of CCR2 and/or of other related chemokine receptors like } \\
\text { CCR1/CCR5 (e.g., cenicriviroc). }\end{array}$ & 103,120 \\
\hline $\begin{array}{l}\text { Modulatinghepatic macrophage } \\
\text { polarization and function }\end{array}$ & $\begin{array}{l}\text { - nanoparticles influencing hepatic macrophage polarization; } \\
\text { - Delivery of "polarizing" drugs (e.g., dexamethasone) to hepatic macrophages; } \\
\text { - Neutralization of inflammatory effector cytokines like TNF and IL-1; } \\
\text { - Inhibition of the pro-inflammatory mediator Galectin-3. }\end{array}$ & $123,126,128,129,131,132$ \\
\hline $\begin{array}{l}\text { Augmentation of restorative hepatic } \\
\text { macrophages }\end{array}$ & $\begin{array}{l}\text { - Application of IL-4 to force local proliferation of tissue-remodeling macrophages; } \\
\text { - Autologous cell transfer of in vitro matured and polarized macrophages or of } \\
\text { hematopoietic precursors; } \\
\text { - Inhibition of inflammatory monocyte influx during the regression of fibrosis; } \\
\text { - Injecting apoptotic cells or PS-containing liposomes to accelerate the differentiation } \\
\text { to Ly-6C } 6 C^{\text {low }} \text { macrophages. }\end{array}$ & $20,120,135,136$ \\
\hline
\end{tabular}


izing the relevance of intestinal homeostasis for preventing inflammatory Kupffer cell activation. ${ }^{118}$ Therapeutic interventions aiming at restoring the normal gut microbiome, such as probiotics, antibiotics, fecal microbiota transfer, and sequestration of deoxycholic or other bile acids, might significantly dampen Kupffer cell activation in the liver.

\section{Inhibiting inflammatory monocyte recruitment to injured liver}

The infiltration of inflammatory monocytes into the liver is critically regulated by chemokines, which appears to be an attractive target for therapeutic interventions. The chemokine CCL2 and its receptor CCR2 represent the key pathway for monocyte accumulation in injured livers in mice and men. ${ }^{119}$ The therapeutic potential for targeting this pathway has been exemplarily demonstrated by inhibiting CCL2 using anRNAaptamer molecule, termed mNOX-E36, in mouse models of fibrosis. Antagonizing CCL2 ameliorated steatohepatitis, reduced hepatic angiogenesis, and accelerated regression of liver fibrosis in mice. ${ }^{31,103,120}$ An oral inhibitor of CCR2 and CCR5, cenicriviroc, is currently being tested in a phase $2 b$ clinical trial in patients with non-alcoholic steatohepatitis and fibrosis (Centaur trial, NCT02217475). An alternative (or complementary) strategy could target hematopoietic growth factors that affect monocytopoiesis, their release into the circulation and their accumulation at sites on inflammation. In patients with chronic HCV infection, high levels of macrophage colony stimulating factor (M-CSF)) are associated with pro-inflammatory properties of hepatic macrophages, ${ }^{121}$ indicating that inhibiting M-CSF might hold therapeutic potential in fibrosis. On the other hand, it needs to be considered that patients with advanced stages of liver cirrhosis are jeopardized by severe immune suppression ('immune-paralysis'), and the augmentation of myeloid cell numbers and function by administration of G-CSF has beneficial effects in this group of patients. ${ }^{122}$

\section{Shaping hepatic macrophage function}

It is undoubtedly clear that hepatic macrophages, like macrophages in other tissues, can adapt their phenotype to different microenvironmental cues in the liver. ${ }^{2,4}$ Identifying the critical factors as well as the transcriptional networks that are important in promoting the differentiation will lead to novel therapeutic strategies. Many strategies to shape the functional polarization of macrophages or inhibit their key effector molecules have been suggested. For instance, hepatic macrophages can be very well targeted by nanoparticle-based drug carriers, due to the efficient scavenger function of macrophages in the liver. ${ }^{123}$ However, the type of particles (e.g., liposomes, polymers, micelles) or modifications of their surface chemistry (e.g., peptide modifications, sugar moieties) can already have immune-modulatory effects on hepatic macrophages. For instance, silica nanoparticles by itself can trigger the release of inflammatory cytokines like TNF or IL- $1 \beta$ by Kupffer cells, ${ }^{124}$ while peptide-modified gold nanorods can polarize hepatic macrophages towards the M1 phenotype, ${ }^{125}$ in both instances, mice exposed to these nanoparticles are more susceptible to liver injury. On the other hand, the delivery of dexamethasone to liver macrophages via liposomal constructs can ameliorate experimental liver injury ${ }^{126}$ by mechanisms that are well preserved between mouse and human macrophages. ${ }^{127}$ The specific delivery of anti-inflammatory drugs to hepatic macrophages or even subsets could be potentially further improved by innovative carrier systems, such as mannosylated albumin $^{128}$ or mannose-modified trimethyl chitosan-cysteine (MTC) conjugated nanoparticles. ${ }^{129}$ An alternative (or complementary) strategy could target effector mediators released by hepatic macrophages, e.g., inhibit TNF or deliver IL-10. ${ }^{130}$ However, the broad systemic TNF inhibition by the anti-TNF antibody infliximab carries significant risks, as revealed from studies in patients with acute alcoholic hepatitis that had increased rates of bacterial infections. ${ }^{75}$ Thus, more specific inflammatory mediators are likely better pharmacological targets. Inhibitors against Galectin-3, a protein with pleiotropic functions that is highly upregulated in hepatic macrophages in liver disease models, ${ }^{131,132}$ are currently being explored in early phase clinical trials.

\section{Augmenting the differentiation to restorative macrophages} A striking observation from mouse models of liver fibrosis regression was the existence of restorative macrophages that develop from Ly- $6 \mathrm{C}^{+}$monocyte-derived macrophages in conditions of injury cessation..$^{20}$ Not all of the molecular factors promoting the differentiation to restorative macrophages have been identified so far, ${ }^{133}$ but phagocytosis appears to be a natural trigger for this process. ${ }^{20}$ Shifting the hepatic microenvironment from inflammation to resolution as well as augmenting restorative differentiation pathways in macrophages by delivering phagocytic stimuli (liposomes, apoptotic cells) appear as promising avenues for macrophage-directed therapies especially in chronic liver diseases. ${ }^{134}$ Moreover, therapeutic approaches could also include the transfer of autologous 'beneficial macrophages.' The injection of ex vivo differentiated macrophages was advantageous in a mouse model of liver fibrosis. ${ }^{135}$ This concept is currently being tested in the REpeated AutoLogous Infusions of STem cells in Cirrhosis trial (REALISTIC) in patients with liver cirrhosis, comparing G-CSF injections alone or followed by repeated infusions of hematopoietic stem cells to standard conservative management. ${ }^{136}$

Taken together, the rapid progress in understanding macrophage heterogeneity in acute and chronic liver diseases gives rise to the expectation that we will soon be able to translate these findings into novel therapies in clinical practice.

\section{COMPETING INTEREST}

Work in the laboratory of Frank Tacke has been supported by funding from Noxxon Inc. and Tobira Therapeutics Inc.

\section{ACKNOWLEDGEMENTS}

This work was supported by the US National Institutes on Alcohol Abuse and Alcoholism (U01AA021723 and R21AA022387). This work was supported by the German Research Foundation (DFG; SFB/ 
TRR57, TA434/3-1) and grants from the Interdisciplinary Centre for Clinical Research within the Faculty of Medicine at the RWTH Aachen University.

1 Varol C, Mildner A, Jung S. Macrophages: development and tissue specialization. Annu Rev Immunol 2015; 33: 643-675.

2 Tacke F, Zimmermann HW. Macrophage heterogeneity in liver injury and fibrosis. J Hepatol 2014; 60: 1090-1096.

3 Lavin Y, Winter D, Blecher-Gonen R, David E, Keren-Shaul H, Merad $\mathrm{M}$ et al. Tissue-resident macrophage enhancer landscapes are shaped by the local microenvironment. Cell 2014; 159: 13121326.

4 Xue J, Schmidt SV, Sander J, Draffehn A, Krebs W, Quester I et al. Transcriptome-based network analysis reveals a spectrum model of human macrophage activation. Immunity 2014; 40: 274-288.

5 Dal-Secco D, Wang J, Zeng Z, Kolaczkowska E, Wong CH, Petri B et al. A dynamic spectrum of monocytes arising from the in situ reprogramming of CCR $2+$ monocytes at a site of sterile injury. J Exp Med 2015; 212: 447-456.

6 Epelman S, Lavine KJ, Randolph GJ. Origin and functions of tissue macrophages. Immunity 2014; 41: 21-35.

7 Karlmark KR, Weiskirchen R, Zimmermann HW, Gassler N, Ginhoux $\mathrm{F}$, Weber $\mathrm{C}$ et al. Hepatic recruitment of the inflammatory Gr1+ monocyte subset upon liver injury promotes hepatic fibrosis. Hepatology 2009; 50: 261-274.

8 Gomez PE, Klapproth K, Schulz C, Busch K, Azzoni E, Crozet L et al. Tissue-resident macrophages originate from yolk-sac-derived erythro-myeloid progenitors. Nature 2015; 518: 547-551.

9 Yona S, Kim KW, Wolf Y, Mildner A, Varol D, Breker M et al. Fate mapping reveals origins and dynamics of monocytes and tissue macrophages under homeostasis. Immunity 2013; 38: 79-91.

10 Schulz C, Gomez PE, Chorro L, Szabo-Rogers H, Cagnard N, Kierdorf $\mathrm{K}$ et al. A lineage of myeloid cells independent of Myb and hematopoietic stem cells. Science 2012; 336: 86-90.

11 Heymann F, Peusquens J, Ludwig-Portugall I, Kohlhepp M, Ergen C, Niemietz $\mathrm{P}$ et al. Liver inflammation abrogates immunological tolerance induced by Kupffer cells. Hepatology 2015; 62: 279291.

12 Antoniades CG, Quaglia A, Taams LS, Mitry RR, Hussain M, Abeles R et al. Source and characterization of hepatic macrophages in acetaminophen-induced acute liver failure in humans. Hepatology 2012; 56: 735-746.

13 Gonzalez-Dominguez E, Samaniego R, Flores-Sevilla JL, CamposCampos SF, Gómez-Campos G, Salas A et al. CD163L1 and CLEC5A discriminate subsets of human resident and inflammatory macrophages in vivo. J Leukoc Biol 2015; 98: 453-466.

14 Tacke F, Randolph GJ. Migratory fate and differentiation of blood monocyte subsets. Immunobiology 2006; 211: 609-618.

15 Ingersoll MA, Spanbroek R, Lottaz C, Gautier EL, Frankenberger M, Hoffmann $\mathrm{R}$ et al. Comparison of gene expression profiles between human and mouse monocyte subsets. Blood 2010; 115: e10-e19.

16 Carlin LM, Auffray C, Geissmann F. Measuring intravascular migration of mouse Ly6C(low) monocytes in vivo using intravital microscopy. Curr Protoc Immunol 2013; Chapter 14:Unit 14.33.1-16.

17 Carlin LM, Stamatiades EG, Auffray C, Hanna RN, Glover L, VizcayBarrena G et al. Nr4a1-dependent Ly6C(low) monocytes monitor endothelial cells and orchestrate their disposal. Cell 2013; 153 : 362-375.

18 Collison JL, Carlin LM, Eichmann M, Geissmann F, Peakman M. Heterogeneity in the locomotory behavior of human monocyte subsets over human vascular endothelium in vitro. $J$ Immunol 2015; 195: 1162-1170.

19 Heymann F, Hammerich L, Storch D, Bartneck M, Huss S, Rüsseler V et al. Hepatic macrophage migration and differentiation critical for liver fibrosis is mediated by the chemokine receptor $\mathrm{C}-\mathrm{C}$ motif chemokine receptor 8 in mice. Hepatology 2012; 55: 898-909.
20 Ramachandran P, Pellicoro A, Vernon MA, Boulter L, Aucott RL, Ali A et al. Differential Ly-6C expression identifies the recruited macrophage phenotype, which orchestrates the regression of murine liver fibrosis. Proc Natl Acad Sci U S A 2012; 109: E3186-E3195.

21 You Q, Holt M, Yin H, Li G, Hu CJ, Ju C. Role of hepatic resident and infiltrating macrophages in liver repair after acute injury. Biochem Pharmacol 2013; 86: 836-843.

22 Liaskou E, Zimmermann HW, Li KK, Oo YH, Suresh S, Stamataki Z et al. Monocyte subsets in human liver disease show distinct phenotypic and functional characteristics. Hepatology 2013; 57: 385-398.

23 Zimmermann HW, Seidler S, Nattermann J, Nikolaus Gassler, Claus Hellerbrand, Alma Zernecke et al. Functional contribution of elevated circulating and hepatic non-classical CD14CD16 monocytes to inflammation and human liver fibrosis. PLoS One 2010; 5: e11049.

24 Jenne CN, Kubes P. Immune surveillance by the liver. Nat Immunol 2013; 14: 996-1006.

25 Knolle P, Schlaak J, Uhrig A, Kempf P, Meyer zum Büschenfelde KH, Gerken G. Human Kupffer cells secrete IL-10 in response to lipopolysaccharide (LPS) challenge. J Hepatol 1995; 22: 226-229.

26 You Q, Cheng L, Kedl RM, Ju C. Mechanism of T cell tolerance induction by murine hepatic Kupffer cells. Hepatology 2008; 48: 978-990.

27 Yan ML, Wang YD, Tian YF, Lai ZD, Yan LN. Inhibition of allogeneic T-cell response by Kupffer cells expressing indoleamine 2,3dioxygenase. World J Gastroenterol 2010; 16: 636-640.

28 Elsegood CL, Chan CW, Degli-Esposti MA, Wikstrom ME, Domenichini A, Lazarus $\mathrm{K}$ et al. Kupffer cell-monocyte communication is essential for initiating murine liver progenitor cell-mediated liver regeneration. Hepatology 2015; 62: 12721284.

29 Seki E, De MS, Osterreicher CH, Kluwe J, Osawa Y, Brenner DA et al. TLR4 enhances TGF-beta signaling and hepatic fibrosis. Nat Med 2007; 13: 1324-1332.

30 Melgar-Lesmes P, Edelman ER. Monocyte-endothelial cell interactions in the regulation of vascular sprouting and liver regeneration in mouse. J Hepatol 2015; 63: 917-925.

31 Ehling J, Bartneck M, Wei X, Gremse F, Fech V, Möckel D et al. CCL2dependent infiltrating macrophages promote angiogenesis in progressive liver fibrosis. Gut 2014; 63: 1960-1971.

32 Movita D, van de Garde MD, Biesta P, Kim Kreefft, Bart Haagmans, Elina Zuniga et al. Inflammatory monocytes recruited to the liver within 24 hours after virus-induced inflammation resemble Kupffer cells but are functionally distinct. J Virol 2015; 89: 4809-4817.

33 Zigmond E, Samia-Grinberg S, Pasmanik-Chor M, Brazowski E, Shibolet $\mathrm{O}$, Halpern $\mathrm{Z}$ et al. Infiltrating monocyte-derived macrophages and resident kupffer cells display different ontogeny and functions in acute liver injury. J Immunol2014; 193: 344-353.

34 Holt MP, Cheng L, Ju C. Identification and characterization of infiltrating macrophages in acetaminophen-induced liver injury. J Leukoc Biol 2008; 84: 1410-1421.

35 Jenkins SJ, Ruckerl D, Cook PC, Jones LH, Finkelman FD, van Rooijen $\mathrm{N}$ et al. Local macrophage proliferation, rather than recruitment from the blood, is a signature of $\mathrm{TH} 2$ inflammation. Science 2011; 332: 1284-1288.

36 Laskin DL, Gardner CR, Price VF, Jollow DJ. Modulation of macrophage functioning abrogates the acute hepatotoxicity of acetaminophen. Hepatology 1995; 21: 1045-1050.

37 Michael SL, Pumford NR, Mayeux PR, Niesman MR, Hinson JA. Pretreatment of mice with macrophage inactivators decreases acetaminophen hepatotoxicity and the formation of reactive oxygen and nitrogen species. Hepatology 1999; 30: 186-195.

38 Bourdi M, Masubuchi Y, Reilly TP, Amouzadeh HR, Martin JL, George JW et al. Protection against acetaminophen-induced liver injury and lethality by interleukin 10: role of inducible nitric oxide synthase. Hepatology 2002; 35: 289-298. 
39 Ryan PM, Bourdi M, Korrapati MC, Proctor WR, Vasquez RA, Yee SB et al. Endogenous interleukin-4 regulates glutathione synthesis following acetaminophen-induced liver injury in mice. Chem Res Toxicol 2012; 25: 83-93.

40 Yee SB, Bourdi M, Masson MJ, Pohl LR. Hepatoprotective role of endogenous interleukin-13 in a murine model of acetaminopheninduced liver disease. Chem Res Toxicol 2007; 20: 734-744.

41 Campion SN, Johnson R, Aleksunes LM, Goedken MJ, van Rooijen N, Scheffer GL et al. Hepatic Mrp4 induction following acetaminophen exposure is dependent on Kupffer cell function. Am J Physiol Gastrointest Liver Physiol 2008; 295: G294-G304.

42 Ju C, Reilly TP, Bourdi M, Radonovich MF, Brady JN, George JW et al. Protective role of Kupffer cells in acetaminophen-induced hepatic injury in mice. Chem Res Toxicol 2002; 15: 1504-1513.

43 Stutchfield BM, Antoine DJ, Mackinnon AC, Gow DJ, Bain CC, Hawley CA et al. CSF1 Restores innate immunity after liver injury in mice and serum levels indicate outcomes of patients with acute liver failure. Gastroenterology 2015; 149: 1896-1909.e14

44 Morita A, Itoh Y, Toyama T, Fujii H, Nishioji K, Kirishima T et al. Activated Kupffer cells play an important role in intra-hepatic Th1associated necro-inflammation in Concanavalin A-induced hepatic injury in mice. Hepatol Res 2003; 27: 143-150.

45 Schumann J, Wolf D, Pahl A, Brune K, Papadopoulos T, van Rooijen $\mathrm{N}$ et al. Importance of Kupffer cells for T-cell-dependent liver injury in mice. Am J Pathol 2000; 157: 1671-1683.

46 Chen L, Xie XJ, Ye YF, Zhou L, Xie HY, Xie QF et al. Kupffer cells contribute to concanavalin A-induced hepatic injury through a Th1 but not Th17 type response-dependent pathway in mice. Hepatobiliary Pancreat Dis Int 2011; 10: 171-178.

47 Erhardt A, Biburger M, Papadopoulos T, Tiegs G. IL-10, regulatory T cells, and Kupffer cells mediate tolerance in concanavalin Ainduced liver injury in mice. Hepatology 2007; 45: 475-485.

48 Erhardt A, Tiegs G. Tolerance induction in response to liver inflammation. Dig Dis 2010; 28: 86-92.

49 Howard TK, Klintmalm GB, Cofer JB, Husberg BS, Goldstein RM, Gonwa TA. The influence of preservation injury on rejection in the hepatic transplant recipient. Transplantation 1990; 49: 103-107.

50 Abu-Amara M, Yang SY, Tapuria N, Fuller B, Davidson B, Seifalian A. Liver ischemia/reperfusion injury: processes in inflammatory networks-a review. Liver Transp/2010; 16: 1016-1032.

51 Hardonk MJ, Dijkhuis FW, Hulstaert CE, Koudstaal J. Heterogeneity of rat liver and spleen macrophages in gadolinium chloride-induced elimination and repopulation. J Leukoc Biol 1992; 52: 296-302.

52 Giakoustidis DE, Iliadis S, Tsantilas D, Papageorgiou G, Kontos N, Kostopoulou $\mathrm{E}$ et al. Blockade of Kupffer cells by gadolinium chloride reduces lipid peroxidation and protects liver from ischemia/reperfusion injury. Hepatogastroenterology 2003; 50: 1587-1592.

53 Tomiyama K, Ikeda A, Ueki S, Nakao A, Stolz DB, Koike Y et al. Inhibition of Kupffer cell-mediated early proinflammatory response with carbon monoxide in transplant-induced hepatic ischemial reperfusion injury in rats. Hepatology 2008; 48: 1608-1620.

54 Ellett JD, Atkinson C, Evans ZP, Amani Z, Balish E, Schmidt MG et al. Murine Kupffer cells are protective in total hepatic ischemia/ reperfusion injury with bowel congestion through IL-10. J Immunol 2010; 184: 5849-5858.

55 Bamboat ZM, Ocuin LM, Balachandran VP, Obaid H, Plitas G, DeMatteo RP. Conventional DCs reduce liver ischemia/reperfusion injury in mice via IL-10 secretion. J Clin Invest 2010; 120: 559569.

56 Richards JA, Wigmore SJ, Devey LR. Heme oxygenase system in hepatic ischemia-reperfusion injury. World J Gastroenterol. 2010; 16: 6068-6078.

57 Zhai Y, Busuttil RW, Kupiec-Weglinski JW. Liver ischemia and reperfusion injury: new insights into mechanisms of innateadaptive immune-mediated tissue inflammation. Am J Transplant 2011; 11: 1563-1569.

58 Helk E, Bernin H, Ernst T, Jacobs T, Heeren J, Tacke F et al. TNFalpha-mediated liver destruction by Kupffer cells and Ly6Chi monocytes during Entamoeba histolytica infection. PLoS Pathog 2013; 9: e1003096.

59 Morias Y, Abels C, Laoui D, Guilliams M, Schouppe E, Tacke F et al. Ly6C- Monocytes Regulate Parasite-Induced Liver Inflammation by Inducing the Differentiation of Pathogenic Ly6C+ Monocytes into Macrophages. PLoS Pathog 2015; 11: e1004873.

60 Karakucuk I, Dilly SA, Maxwell JD. Portal tract macrophages are increased in alcoholic liver disease. Histopathology 1989; 14: 245-253.

61 Tapia-Abellan A, Martinez-Esparza M, Ruiz-Alcaraz AJ, HernándezCaselles T, Martínez-Pascual C, Miras-López M et al. The peritoneal macrophage inflammatory profile in cirrhosis depends on the alcoholic or hepatitis $C$ viral etiology and is related to ERK phosphorylation. BMC Immunol 2012; 13: 42.

62 Lee J, French B, Morgan T, French SW. The liver is populated by a broad spectrum of markers for macrophages. In alcoholic hepatitis the macrophages are M1 and M2. Exp Mol Pathol 2014; 96: 118125.

63 Luna-Casado L, Diez-Ruiz A, Gutierrez-Gea F, Santos-Perez JL, Rico-Irles J, Wachter $\mathrm{H}$ et al. Increased peripheral mononuclear cells expression of adhesion molecules in alcoholic cirrhosis: its relation to immune activation. J Hepatol 1997; 27: 477-483.

64 Afford SC, Fisher NC, Neil DA, Fear J, Brun P, Hubscher SG et al. Distinct patterns of chemokine expression are associated with leukocyte recruitment in alcoholic hepatitis and alcoholic cirrhosis. J Pathol 1998; 186: 82-89.

65 Fisher NC, Neil DA, Williams A, Adams DH. Serum concentrations and peripheral secretion of the beta chemokines monocyte chemoattractant protein 1 and macrophage inflammatory protein 1alpha in alcoholic liver disease. Gut 1999; 45: 416-420.

66 McClain CJ, Barve S, Deaciuc I, Kugelmas M, Hill D. Cytokines in alcoholic liver disease. Semin Liver Dis 1999; 19: 205-219.

67 Gobejishvili L, Barve S, Joshi-Barve S, Uriarte S, Song Z, McClain C. Chronic ethanol-mediated decrease in CAMP primes macrophages to enhanced LPS-inducible NF-kappaB activity and TNF expression: relevance to alcoholic liver disease. Am J Physiol Gastrointest Liver Physiol 2006; 291: G681-G688.

68 Zhang Z, Bagby GJ, Stoltz D, Oliver P, Schwarzenberger PO, Kolls JK. Prolonged ethanol treatment enhances lipopolysaccharide/phorbol myristate acetate-induced tumor necrosis factor-alpha production in human monocytic cells. Alcohol Clin Exp Res 2001; 25: 444-449.

69 Enomoto N, Ikejima K, Bradford BU, Rivera CA, Kono H, Goto M et al. Role of Kupffer cells and gut-derived endotoxins in alcoholic liver injury. J Gastroenterol Hepatol 2000;15 Suppl: D20-D25.

70 Petrasek J, Bala S, Csak T, Lippai D, Kodys K, Menashy V et al. IL-1 receptor antagonist ameliorates inflammasome-dependent alcoholic steatohepatitis in mice. J Clin Invest 2012; 122: 34763489.

71 Koop DR, Klopfenstein B, limuro Y, Thurman RG. Gadolinium chloride blocks alcohol-dependent liver toxicity in rats treated chronically with intragastric alcohol despite the induction of CYP2E1. Mol Pharmacol 1997; 51: 944-950.

72 Mandrekar P, Ambade A, Lim A, Szabo G, Catalano D. An essential role for monocyte chemoattractant protein-1 in alcoholic liver injury: regulation of proinflammatory cytokines and hepatic steatosis in mice. Hepatology 2011; 54: 2185-2197.

73 Nagy LE. Recent insights into the role of the innate immune system in the development of alcoholic liver disease. Exp Biol Med (Maywood) 2003; 228: 882-890.

74 Wang M, You Q, Lor K, Chen F, Gao B, Ju C. Chronic alcohol ingestion modulates hepatic macrophage populations and functions in mice. J Leukoc Biol 2014; 96: 657-665.

75 Naveau S, Chollet-Martin S, Dharancy S, Mathurin P, Jouet P, Piquet MA et al. A double-blind randomized controlled trial of infliximab associated with prednisolone in acute alcoholic hepatitis. Hepatology 2004; 39: 1390-1397.

76 Ganem D, Prince AM. Hepatitis B virus infection-natural history and clinical consequences. N Engl J Med 2004; 350: 1118-1129.

77 Lauer GM, Walker BD. Hepatitis C virus infection. N Eng/ J Med 2001; 345: 41-52. 
78 Tu Z, Pierce RH, Kurtis J, Kuroki Y, Crispe IN, Orloff MS. Hepatitis C virus core protein subverts the antiviral activities of human Kupffer cells. Gastroenterology 2010; 138: 305-314.

79 Chang S, Dolganiuc A, Szabo G. Toll-like receptors 1 and 6 are involved in TLR2-mediated macrophage activation by hepatitis $C$ virus core and NS3 proteins. J Leukoc Biol 2007; 82: 479-487.

80 Hosomura N, Kono H, Tsuchiya M, Ishii K, Ogiku M, Matsuda M et al. HCV-related proteins activate Kupffer cells isolated from human liver tissues. Dig Dis Sci 2011; 56: 1057-1064.

81 Khakoo SI, Soni PN, Savage K, Brown D, Dhillon AP, Poulter LW et al. Lymphocyte and macrophage phenotypes in chronic hepatitis $C$ infection. Correlation with disease activity. Am J Pathol 1997; 150: 963-970.

82 McGuinness PH, Painter D, Davies S, McCaughan GW. Increases in intrahepatic CD68 positive cells, MAC387 positive cells, and proinflammatory cytokines (particularly interleukin 18 ) in chronic hepatitis C infection. Gut 2000; 46: 260-269.

83 Burgio VL, Ballardini G, Artini M, Caratozzolo M, Bianchi FB, Levrero M. Expression of co-stimulatory molecules by Kupffer cells in chronic hepatitis of hepatitis C virus etiology. Hepatology 1998; 27: 1600-1606.

84 Dolganiuc A, Norkina O, Kodys K, Catalano D, Bakis G, Marshall C et al. Viral and host factors induce macrophage activation and loss of toll-like receptor tolerance in chronic HCV infection. Gastroenterology 2007; 133: 1627-1636.

85 Shrivastava S, Mukherjee A, Ray R, Ray RB. Hepatitis C virus induces interleukin-1beta (IL-1 beta)/IL-18 in circulatory and resident liver macrophages. J Virol 2013; 87: 12284-12290.

86 Boltjes A, Movita D, Boonstra A, Woltman AM. The role of Kupffer cells in hepatitis B and hepatitis $C$ virus infections. J Hepato/ 2014; 61: 660-671.

87 Broering R, Wu J, Meng Z, Hilgard P, Lu M, Trippler M et al. Toll-like receptor-stimulated non-parenchymal liver cells can regulate hepatitis C virus replication. J Hepatol 2008; 48: 914-922.

88 Zhu H, Liu C. Interleukin-1 inhibits hepatitis C virus subgenomic RNA replication by activation of extracellular regulated kinase pathway. J Virol 2003; 77: 5493-5498.

89 Zhu H, Shang X, Terada N, Liu C. STAT3 induces anti-hepatitis C viral activity in liver cells. Biochem Biophys Res Commun 2004; 324: 518-528.

90 Tordjmann T, Soulie A, Guettier C, Schmidt M, Berthou C, Beaugrand $\mathrm{M}$ et al. Perforin and granzyme $\mathrm{B}$ lytic protein expression during chronic viral and autoimmune hepatitis. Liver 1998; 18: 391-397.

91 Tang TJ, Kwekkeboom J, Laman JD, Niesters HG, Zondervan PE, de Man RA et al. The role of intrahepatic immune effector cells in inflammatory liver injury and viral control during chronic hepatitis B infection. J Viral Hepat 2003; 10: 159-167.

92 Kolios G, Valatas V, Kouroumalis E. Role of Kupffer cells in the pathogenesis of liver disease. World J Gastroenterol 2006; 12: 7413-7420.

93 Chang S, Dolganiuc A, Szabo G. Toll-like receptors 1 and 6 are involved in TLR2-mediated macrophage activation by hepatitis $C$ virus core and NS3 proteins. J Leukoc Biol 2007; 82: 479-487.

$94 \mathrm{Li} \mathrm{H}$, Zheng HW, Chen H, Xing ZZ, You H, Cong M et al. Hepatitis B virus particles preferably induce Kupffer cells to produce TGF-beta1 over pro-inflammatory cytokines. Dig Liver Dis 2012; 44: 328-333.

95 Mengshol JA, Golden-Mason L, Arikawa T, Smith M, Niki T, McWilliams $\mathrm{R}$ et al. A crucial role for Kupffer cell-derived galectin9 in regulation of T cell immunity in hepatitis $C$ infection. PLoS One 2010; 5: e9504.

96 Sandler NG, Koh C, Roque A, Smith M, Niki T, McWilliams R et al. Host response to translocated microbial products predicts outcomes of patients with HBV or HCV infection. Gastroenterology 2011; 141: $1220-1230$

97 Nebbia G, Peppa D, Schurich A, Khanna P, Singh HD, Cheng Y et al. Upregulation of the Tim-3/galectin-9 pathway of T cell exhaustion in chronic hepatitis B virus infection. PLoS One 2012; 7: e47648.

98 Wallace K, Burt AD, Wright MC. Liver fibrosis. Biochem J 2008; 411: 1-18.
99 Pradere JP, Kluwe J, De MS, Jiao JJ, Gwak GY, Dapito DH et al. Hepatic macrophages but not dendritic cells contribute to liver fibrosis by promoting the survival of activated hepatic stellate cells in mice. Hepatology 2013; 58: 1461-1473.

100 Fallowfield JA, Mizuno M, Kendall TJ, Constandinou CM, Benyon RC, Duffield JS et al. Scar-associated macrophages are a major source of hepatic matrix metalloproteinase-13 and facilitate the resolution of murine hepatic fibrosis. J Immunol 2007; 178: 5288-5295.

101 Pellicoro A, Aucott RL, Ramachandran P, Robson AJ, Fallowfield JA, Snowdon VK et al. Elastin accumulation is regulated at the level of degradation by macrophage metalloelastase (MMP-12) during experimental liver fibrosis. Hepatology 2012; 55: 1965-1975.

102 Duffield JS, Forbes SJ, Constandinou CM, Clay S, Partolina M, Vuthoori $S$ et al. Selective depletion of macrophages reveals distinct, opposing roles during liver injury and repair. J Clin Invest 2005; 115: 56-65.

103 Baeck C, Wehr A, Karlmark KR, Heymann F, Vucur M, Gassler N et al. Pharmacological inhibition of the chemokine CCL2 (MCP-1) diminishes liver macrophage infiltration and steatohepatitis in chronic hepatic injury. Gut 2012; 61: 416-426.

104 Capece D, Fischietti M, Verzella D, Gaggiano A, Cicciarelli G, Tessitore $A$ et al. The inflammatory microenvironment in hepatocellular carcinoma: a pivotal role for tumor-associated macrophages. Biomed Res Int 2013; 2013: 187204.

105 Naugler WE, Sakurai T, Kim S, Maeda S, Kim K, Elsharkawy AM et al. Gender disparity in liver cancer due to sex differences in MyD88-dependent IL-6 production. Science 2007; 317: 121-124.

106 Wu J, Li J, Salcedo R, Mivechi NF, Trinchieri G, Horuzsko A. The proinflammatory myeloid cell receptor TREM-1 controls Kupffer cell activation and development of hepatocellular carcinoma. Cancer Res 2012; 72: 3977-3986.

107 Wan S, Zhao E, Kryczek I, Mivechi NF, Trinchieri G, Horuzsko A. Tumor-associated macrophages produce interleukin 6 and signal via STAT3 to promote expansion of human hepatocellular carcinoma stem cells. Gastroenterology 2014; 147: 1393-1404.

108 Wu K, Kryczek I, Chen L, Zou W, Welling TH. Kupffer cell suppression of CD8+ T cells in human hepatocellular carcinoma is mediated by $\mathrm{B} 7-\mathrm{H} 1 /$ programmed death-1 interactions. Cancer Res 2009; 69: 8067-8075.

109 Kuang DM, Zhao Q, Peng C, Xu J, Zhang JP, Wu C et al. Activated monocytes in peritumoral stroma of hepatocellular carcinoma foster immune privilege and disease progression through PD-L1. J Exp Med 2009; 206: 1327-1337.

110 Ding T, Xu J, Wang F, Shi M, Zhang Y, Li S-P et al. High tumorinfiltrating macrophage density predicts poor prognosis in patients with primary hepatocellular carcinoma after resection. Hum Pathol 2009; 40: 381-389.

111 Ikeda M, Ohkawa S, Okusaka T, Mitsunaga S, Kobayashi S, Morizane C et al. Japanese phase I study of GC33, a humanized antibody against glypican-3 for advanced hepatocellular carcinoma. Cancer Sci 2014; 105: 455-462.

112 Zhu AX, Gold PJ, El-Khoueiry AB, Abrams TA, Morikawa H, Ohishi N et al. First-in-man phase I study of GC33, a novel recombinant humanized antibody against glypican-3, in patients with advanced hepatocellular carcinoma. Clin Cancer Res 2013; 19: 920-928.

113 Rogers TL, Wind N, Hughes R, Nutter F, Brown HK, Vasiliadou I et al. Macrophages as potential targets for zoledronic acid outside the skeleton-evidence from in vitro and in vivo models. Cell Oncol (Dordr.) 2013; 36: 505-514.

114 Coscia M, Quaglino E, lezzi M, Curcio C, Pantaleoni F, Riganti C et al. Zoledronic acid repolarizes tumour-associated macrophages and inhibits mammary carcinogenesis by targeting the mevalonate pathway. J Cell Mol Med 2010; 14: 2803-2815.

115 Schnabl B, Brenner DA. Interactions between the intestinal microbiome and liver diseases. Gastroenterology 2014; 146: 1513-1524.

116 Qin N, Yang F, Li A, Prifti E, Chen Y, Shao L et al. Alterations of the human gut microbiome in liver cirrhosis. Nature2014; 513: 59-64. 
117 Dapito DH, Mencin A, Gwak GY, Pradere JP, Jang MK, Mederacke et al. Promotion of hepatocellular carcinoma by the intestinal microbiota and TLR4. Cancer Cell 2012; 21: 504-516.

118 Mazagova M, Wang L, Anfora AT, Wissmueller M, Lesley SA, Miyamoto $Y$ et al. Commensal microbiota is hepatoprotective and prevents liver fibrosis in mice. FASEB J 2015; 29: 1043-1055.

119 Marra F, Tacke F. Roles for chemokines in liver disease. Gastroenterology 2014; 147: 577-594.

120 Baeck C, Wei X, Bartneck M, Fech V, Heymann F, Gassler N et al. Pharmacological inhibition of the chemokine C-C motif chemokine ligand 2 (monocyte chemoattractant protein 1 ) accelerates liver fibrosis regression by suppressing Ly-6C(+) macrophage infiltration in mice. Hepatology 2014; 59: 1060-1072.

121 Preisser L, Miot C, Le Guillou-Guillemette H, Beaumont E, Foucher ED, Garo E et al. IL-34 and macrophage colony-stimulating factor are overexpressed in hepatitis $\mathrm{C}$ virus fibrosis and induce profibrotic macrophages that promote collagen synthesis by hepatic stellate cells. Hepatology 2014; 60: 1879-1890.

122 Kedarisetty CK, Anand L, Bhardwaj A, Bhadoria AS, Kumar G, Vyas AK et al. Combination of granulocyte colony-stimulating factor and erythropoietin improves outcomes of patients with decompensated cirrhosis. Gastroenterology 2015; 148: 1362-1370.

123 Bartneck M, Warzecha KT, Tacke F. Therapeutic targeting of liver inflammation and fibrosis by nanomedicine. Hepatobiliary Surg Nutr 2014; 3: 364-376.

124 Liu T, Li L, Fu C, Liu H, Chen D, Tang F. Pathological mechanisms of liver injury caused by continuous intraperitoneal injection of silica nanoparticles. Biomaterials 2012; 33: 2399-2407.

125 Bartneck M, Ritz T, Keul HA, Wambach M, Bornemann J, Gbureck U et al. Peptide-functionalized gold nanorods increase liver injury in hepatitis. ACS Nano 2012; 6: 8767-8777.

126 Bartneck M, Scheyda KM, Warzecha KT, Rizzo LY, Hittatiya K, Luedde $\mathrm{T}$ et al. Fluorescent cell-traceable dexamethasone-loaded liposomes for the treatment of inflammatory liver diseases. Biomaterials 2015; 37: 367-382.

127 Bartneck M, Peters FM, Warzecha KT, Bienert M, van Bloois L, Trautwein $\mathrm{C}$ et al. Liposomal encapsulation of dexamethasone modulates cytotoxicity, inflammatory cytokine response, and migratory properties of primary human macrophages. Nanomedicine 2014; 10: 1209-1220.
128 Melgert BN, Olinga P, Van Der Laan JM, Weert B, Cho J, Schuppan D et al. Targeting dexamethasone to Kupffer cells: effects on liver inflammation and fibrosis in rats. Hepatology 2001; 34: 719-728.

$129 \mathrm{He}$ C, Yin L, Tang C, Yin C. Multifunctional polymeric nanoparticles for oral delivery of TNF-alpha siRNA to macrophages. Biomaterials 2013; 34: 2843-2854.

130 Hammerich L, Tacke F. Interleukins in chronic liver disease: lessons learned from experimental mouse models. Clin Exp Gastroenterol 2014; 7: 297-306.

131 Traber PG, Chou H, Zomer E, Hong F, Klyosov A, Fiel M-I et al. Regression of fibrosis and reversal of cirrhosis in rats by galectin inhibitors in thioacetamide-induced liver disease. PLoS One 2013; 8: e75361.

132 Traber PG, Zomer E. Therapy of experimental NASH and fibrosis with galectin inhibitors. PLoS One 2013; 8: e83481.

133 Iredale JP, Bataller R. Identifying molecular factors that contribute to resolution of liver fibrosis. Gastroenterology 2014; 146: 11601164.

134 Tacke F, Trautwein C. Mechanisms of liver fibrosis resolution. J Hepatol 2015; 63: 1038-1039.

135 Thomas JA, Pope C, Wojtacha D, Robson AJ, Gordon-Walker TT, Hartland $S$ et al. Macrophage therapy for murine liver fibrosis recruits host effector cells improving fibrosis, regeneration, and function. Hepatology 2011; 53: 2003-2015.

136 King A, Barton D, Beard HA, Ni Than N, Moore J, Corbett C et al. REpeated AutoLogous Infusions of STem cells In Cirrhosis (REALISTIC): a multicentre, phase II, open-label, randomised controlled trial of repeated autologous infusions of granulocyte colony-stimulating factor (GCSF) mobilised CD133+ bone marrow stem cells in patients with cirrhosis. A study protocol for a randomised controlled trial. BMJ Open 2015; 5: e007700.

This license allows readers to copy, distribute and transmit the Contribution as long as it attributed back to the author. Readers are permitted to alter, transform or build upon the Contribution as long as the resulting work is then distributed under this is a similar license. Readers are not permitted to use the Contribution for commercial purposes. Please read the full license for further details at - http://creativecommons.org/licenses/by-nc-sa/4.0/ 